\title{
Breed and age effects on concentration of adiponectin and reproductive performance in Anglo Nubian, Etawah grade and its crossbred bucks
}

\author{
HAFIZUDDIN $^{1, \boldsymbol{}}$, NI WAYAN KURNIANI KARJA ${ }^{2}$, LISA PRAHARANI ${ }^{3}$, MOHAMAD AGUS SETIADI ${ }^{2}$ \\ ${ }^{1}$ Laboratory of Reproduction, Faculty of Veterinary Medicine, Universitas Syiah Kuala. Jl. Teungku Hasan Krueng Kalee No. 4, Kopelma Darussalam, \\ Banda Aceh 23111, Aceh, Indonesia. Tel.: +62-651-7551536, `email: hafizuddin_umar@unsyiah.ac.id \\ ${ }^{2}$ Division of Reproduction and Obstetrics, Department of Veterinary Clinic, Reproduction and Pathology, Faculty of Veterinary Medicine, \\ Institut Pertanian Bogor. Jl. Agatis, IPB University Campus Dramaga, Bogor 16680, West Java, Indonesia \\ ${ }^{3}$ Indonesian Research Institute for Animal Production. Jl. Banjarwaru, Ciawi, Bogor 16720, West Java, Indonesia
}

Manuscript received: 15 December 2020. Revision accepted: 1 February 2021.

\begin{abstract}
Hafizuddin, Karja NWK, Praharani L, Setiadi MA. 2021. Breed and age effects on concentration of adiponectin and reproductive performance in Anglo Nubian, Etawah grade and its crossbred bucks. Biodiversitas 22: 1112-1119. The purpose of this study was to evaluate the effect of differences in breed and age on reproductive performance and adiponectin and testosterone production in Anglo Nubian, Etawah grade, and crossbred (Anpera) bucks. A total of 12 bucks with four individuals of each breed were used. This study collected five data points from each buck regarding adiponectin, testosterone, and reproductive performance (libido and semen characteristics). Data were analyzed with factorial analysis of variance and Duncan's test. The result shows that adiponectin concentration between breeds was significantly different $(\mathrm{P}<0.01)$. There were also significant differences $(\mathrm{P}<0.05)$ in adiponectin concentrations based on buck age. There were also significant interactions with adiponectin concentrations $(\mathrm{P}<0.01)$. Furthermore, testosterone concentrations showed significant differences based on breed $(\mathrm{P}<0.05)$ and age $(\mathrm{P}<0.05)$. There were also significant agebreed interactions affecting testosterone concentrations $(\mathrm{P}<0.01)$. Libido and semen characteristics had no significant differences based on breed and age group, and no significant age-breed interactions $(\mathrm{P}>0.05)$. The heterosis effect on adiponectin concentration (48.05\%), testosterone concentration (27.68\%), libido $(-0.61 \%)$, semen volume $(-1.93 \%)$, sperm motility $(0.49 \%)$, sperm normal morphology $(0.18 \%)$, and sperm concentration $(0.00 \%)$ was measured. In conclusion, there is a significant effect of breed, age, and age-breed interactions on the concentration of adiponectin and testosterone in bucks, and both of these variables have a high heterosis effect on crossbred bucks.
\end{abstract}

Keywords: Adiponectin, bucks, libido, semen quality, testosterone

\section{INTRODUCTION}

Crossbreeding is a breeding process for increasing local livestock production through crossing with exotic animals (Mirkena et al. 2010; Sutarno and Setyawan 2015). Crosses aim to combine the superior nature of the two parents. Crosses in goats generally aim to increase meat production, milk production, and reproductive performance (Sahraoui et al. 2020). In the tropics, crossing also aims to produce high productivity livestock adaptive to the tropical climate (Arief et al. 2020). One of the efforts made in Indonesia to increase the production of goat milk is by crossing the Anglo Nubian goat with the Etawah grade, producing what is known as the Anpera goat. For this reason, the reproductive performance of Anpera goat bulls must be evaluated to better select individuals and improve the breeding process.

Recent studies by Hafizuddin et al. (2020) show that the hormone adiponectin correlates with buck semen characteristics, starting with variances in semen volume, sperm morphology, and sperm concentration. This corroborates previous reports on male mammals (Kasimanickam et al. 2013; Thomas et al. 2013; Kadivar et al. 2016). Additionally, adiponectin has been proposed as a biomarker candidate for semen quality and male fertility
(Thomas et al. 2013; Elfassy et al. 2018; Hafizuddin et al. 2019). Previously, parameters commonly used to assess reproductive performance in male mammals ranged from testosterone (Singh et al. 2014), to libido (Fahey et al. 2012), and semen quality (Boe-Hansen et al. 2015). Some reports also found that adiponectin concentration is influenced by age (Heinz et al. 2015; Choubey et al. 2019). However, the effect of breed on adiponectin has not yet been reported. Therefore, research is needed to determine how adiponectin concentration and reproductive performance in bucks are affected by age and breed, an effect known as heterosis.

Adiponectin is a protein hormone produced by adipose tissue. Recent reports on male mammals show that adiponectin is correlated with fertility, varying testosterone and semen quality (Pfeffer et al. 2007; Kasimanickam et al. 2013; Thomas et al. 2013; Kadivar et al. 2016). At the same time, testosterone is a steroid hormone actively involved in the process of spermatogenesis. It can be used to calculate male fertility in combination with physical parameters and semen quality (Singh et al. 2014). Additionally, libido is a parameter of male fertility (Fahey et al. 2012). Some studies describe new developments in fertility determination that use adiponectin as a new parameter. However, factors that influence adiponectin are 
still varied, and until now, the effects of heterosis in crossing animals have not been reported.

The purpose of this study is to evaluate the effect of differences in breed and age on adiponectin, testosterone, and reproductive performance in Anglo Nubian, Etawah grade, and crossbred (Anpera) bucks. This research provides new information and confirms the role of genetics on functional hormones involved in reproduction.

\section{MATERIALS AND METHODS}

\section{Ethical statement}

The use of treated animals in this study was ethically ratified by the Animal Care and Use Committee (ACUC) of IPB University (Bogor Agricultural University), Bogor, Indonesia, number: 81-2017 IPB.

\section{Animals}

The samples used in this study were semen and blood collected from 12 bucks, weighing between 36 and $69 \mathrm{~kg}$ and 18-42 months old. The bucks belonged to the Indonesian Research Institute for Animal Production and were raised in individual cages. The bucks were fed 3-4 kg of king grass and $0.5-0.7 \mathrm{~kg}$ of concentrate daily, water consumption ad libitum. Bucks were classified into three breed groups: Anglo Nubian $(n=4)$, Etawah grade $(n=4)$ and Anpera $(n=4)$. They were also classified by age: young (18-24 months) and adult (30-42 months). Observations of libido, collection and evaluation of semen, and collection of blood samples from each animal were conducted in the morning. All data were collected in five repetitions at 10day intervals. To standardize collection, all animal samples were treated by semen collection one day before the first sample was collected.

\section{Blood collection and processing}

Blood was collected from the jugular vein, ranging between 1.5 and $1.8 \mathrm{ml}$, using a $3 \mathrm{~mL}$ disposable syringe filled with the anticoagulant ethylenediaminetetraacetic acid ethylene diamine (EDTA) (Art. 8418 Titriplex ${ }^{\circledR}$ III, Merck, Darmstadt, Germany). The blood was then centrifuged at $5000 \mathrm{rpm}$ at room temperature for 10 minutes. The supernatant (blood plasma) was poured into a microtube and stored at $-20^{\circ} \mathrm{C}$ until adiponectin and testosterone analysis.

\section{Adiponectin concentration measurements}

Adiponectin concentrations were measured with the goat adiponectin enzyme-linked immunosorbent assay (ELISA) kit produced by Bioassay Technology Laboratory, Shanghai Crystal Day Biotech Co., Ltd., China (Cat. No E0020GO). This assay has been successfully validated for measuring adiponectin concentrations in Anpera buck blood plasma. Adiponectin measurement was performed by manufacturer's instructions, according to Hafizuddin et al. (2020). Briefly, $50 \mu$ adiponectin standard were added to standard wells and $40 \mu \mathrm{L}$ of blood plasma sample) were placed in the sample wells. Ten $\mu$ of anti-adiponectin antibody and $50 \mu \mathrm{l}$ of streptavidin-horseradish peroxidase (HRP) were then added to the sample wells, standard well, and control well. The control well was filled only with 10 $\mu \mathrm{L}$ of anti-adiponectin antibody and $50 \mu \mathrm{l}$ of streptavidinHRP. The filled plate was then thoroughly mixed, covered with a sealer, and incubated for 60 minutes at $37{ }^{\circ} \mathrm{C}$. The sealer was removed and the plate was rinsed with a rinsing buffer 5 times. The wells were immersed in $0.35 \mathrm{ml}$ rinsing buffer for 30 seconds to 1 minute each rinse. After rinsing, the wells were thumped firmly on absorbent paper to remove any residual clumps. Substrate A and B $(50 \mu \mathrm{l})$ were added to each well, respectively. The plate was separated and covered using a new sealer for 10 minutes at $37{ }^{\circ} \mathrm{C}$. The enzyme reaction was stopped using $50 \mu \mathrm{l}$ of stop solution. The absorbance (optical density) was measured by ELISA reader.

\section{Testosterone concentration measurements}

The testosterone concentration was analyzed by ELISA testosterone kit. Testosterone concentration measurement was done based on the DRG diagnostic instruction manual (Cat. no. EIA-1559, DRG Instruments GmbH, Germany). Testosterone measurements were conducted following manufacturer's instructions as described by Hafizuddin et al. (2020). Standard, control, and blood plasma samples (25 $\mu \mathrm{l})$ in duplicate were added into appropriate microplate wells coated with testosterone monoclonal antibody. After the addition of $200 \mu \mathrm{l}$ enzyme conjugate, each well was incubated for 60 minutes. The plates were then washed with washing solution and blotted dry four times. Then, each well-received $200 \mu \mu$ substrate solution (tetramethylbenzidine), and re-incubated 15-20 minutes. The complete procedure was conducted at room temperature. The enzyme reaction was stopped using 100 $\mu \mathrm{l} 0.5 \mathrm{M} \mathrm{H}_{2} \mathrm{SO}_{4}$. The absorbance was measured at $450 \mathrm{~nm}$ using ELISA reader.

\section{Libido examinations}

The libido of the Anpera bucks was evaluated according to the method reported by Mickelsen et al. (1982). Libido was scored ranging from 0 to 10: 0 . no interest; 1 . interest only in one event; 2 . more than one interest or occurrence; score 3 . active interest during the whole test period; 4 . one mount or attempt to mount, no intromission; 5. two mounts or attempts to mount, without intromission; 6. >2mounts or attempts to mount, no intromission; 7. one intromission, no further interest; score 8. one intromission followed by interest; score 9. two intromissions, no further interest; score 10. two intromissions followed by interest (including mounts and/or services).

\section{Semen collection and evaluation}

Semen samples were obtained from each animal and analyzed, as previously reported by Maidin et al. (2018) and Syafruddin et al. (2020). Semen was collected 5 times using an artificial vagina with 10-day intervals, and a labeled tube was used to measure semen volume. Sperm motility, morphology and concentration were evaluated under a microscope (Olympus, Tokyo, Japan). The collected semen was immediately placed in a water bath $\left(37^{\circ} \mathrm{C}\right)$ and evaluated for motility, morphology, and sperm 
concentration. Motility of sperm was evaluated subjectively, whereas morphology and concentration of sperm were evaluated using eosin-nigrosin staining and Neubauer hemocytometer, respectively.

\section{Statistical analysis}

A completely randomized design with two-factor arrangement ( 3 breed $\times 2$ age), with 5 repetitions was used. Results are presented as least square means \pm standard error of means (LS means \pm SEM) (Amal et al. 2019). Effects of breed and age were evaluated by ANOVA, while Duncan's test was used to determine differences among the combination of age and breed, using $\mathrm{SAS} \AA$ program version 9.4. Differences with a P-value of $5 \%$ were considered to be statistically significant.

The effects of heterosis are calculated using a formula as reported Praharani et al. (2019). Heterosis $(\%)=\left(\mathrm{P}_{\mathrm{A}}-(\right.$ $\left.\left.\left(\mathrm{P}_{\mathrm{N}}+\mathrm{P}_{\mathrm{E}}\right) / 2\right)\right) /\left(\left(\mathrm{P}_{\mathrm{N}}+\mathrm{P}_{\mathrm{E}}\right) / 2\right) \mathrm{x} 100 ; \mathrm{P}_{\mathrm{A}}=$ Performance of Anpera; $\mathrm{P}_{\mathrm{N}}=$ Performance of Anglo Nubian; $\mathrm{P}_{\mathrm{E}}=$ Performance of Etawah grade.

\section{RESULTS AND DISCUSSION}

\section{The concentration of adiponectin}

Breed, age, and the interaction between these two factors had an effect on adiponectin concentration with significant difference $(\mathrm{P}<0.05)$ (Table 1$)$. The results of this study showed that the highest concentration of adiponectin was found in Anpera, while the lowest was in Etawah grade $(\mathrm{P}<0.01)$. Adiponectin concentrations were higher in adult bucks than young bucks $(\mathrm{P}<0.05)$. Only in the Anglo Nubian breed were age-breed interactions affecting adiponectin concentrations with significant difference $(\mathrm{P}<0.01)$.

The genetic influence on adiponectin concentration is directly related to the different adipose tissue masses between breeds. The adipose mass is the main determinant influencing adiponectin concentration. This has been reported in beef (German Holstein) and dairy (Charolais) cattle with differences in adipose tissue mass (Ren et al. 2002; Chilliard et al. 2005). Based on this, in terms of the body composition (adipose tissue mass) of Anglo Nubian and Anpera goats, compared to Etawah grade, breed may have a significant effect on adiponectin concentration ( $\mathrm{P}$ $<0.05)$.

This study finds breed is a factor in increasing adiponectin, as shown in the Anglo Nubian breed. Specific factors in goat breed are likely to produce differences in the concentration of adiponectin (Hafizuddin et al. 2020). However, the identification of factors influencing adiponectin concentration, especially in goats, requires further research.

Age increasingly affects adiponectin concentrations in bucks during optimum reproductive period (Hafizuddin et al. 2020). Similarly, Heinz et al. (2015) reported that the older the bulls, the higher the concentration of adiponectin. Heinz et al. (2015) found adiponectin concentrations to be significantly different between bulls $\leq 24$ months compared to bulls age $\geq 72$ months ( $P<0.01$ ). In contrast, Pearson
(2015) found higher adiponectin concentrations in colts compared with stallions, with no significant difference $(\mathrm{P}>$ 0.05). As animals age, adipose tissue undergoes hypertrophy, resulting in increased adiponectin concentration in the blood and increased insulin sensitivity in adipose tissue (Cawthorn et al. 2012; Yu et al. 2019). In comparison, Cnop et al. (2003) and Ayina et al. (2016) report that adiponectin concentration changes are determined by adipose tissue insulin resistance factors, intra-abdominal fat, and lipoprotein profile. Subsequent reports by Ting-Ting et al. (2019), state that increasing lipoprotein has a high correlation with increasing age. This statement supports Pfaehler et al. (2012), who report that lipoprotein positively correlates with adiponectin concentration.

\section{The concentration of testosterone}

Breed,age, and age-breed interactions had an effect on testosterone concentration with significant difference $(\mathrm{P}$ $<0.05$ ) (Table 2). The results of this study show higher testosterone concentrations in Anpera breed than Etawah grade $(\mathrm{P}<0.05)$. Regarding age, testosterone concentrations are higher on average in young bucks than in adult bucks. However, only in the Anglo Nubian breed did age-breed interactions affect testosterone concentration with significant difference $(\mathrm{P}<0.01)$.

This study found significant difference in testosterone concentrations among buck breeds. A similar report by Rachmawati et al. (2014) showed significantly different testosterone concentrations in Kejobong, Bligon, and Etawah grade buck at $12.00 \pm 6.56 \mathrm{ng} / \mathrm{mL}, 9.23 \pm 4.73$ $\mathrm{ng} / \mathrm{mL}$, and $6.82 \pm 4.18 \mathrm{ng} / \mathrm{mL}$, respectively. Meanwhile, Ferasyi et al. (2015) determined a testosterone concentration of $13.20 \pm 3.96 \mathrm{ng} / \mathrm{mL}$ in Etawah grade bucks. Testosterone concentrations of Kacang goats were determined at 10.2 $\pm 5.42 \mathrm{ng} / \mathrm{mL}$ (Armansyah et al. 2018), and 7.25 $\pm 1.45 \mathrm{ng} / \mathrm{mL}$ (Gholib et al. 2016). According to Rachmawati et al. (2014), the differences likely occurred as a result of genetic and breed factors. According to Ohlsson et al. (2011), the factors determining testosterone concentrations include breed, age and body mass index. Furthermore, genetic effects on testosterone concentrations depend on genetic variances found in the sex hormonebinding globulin (SHBG) locus. If the number of genetic variances in the SHBG locus more strongly affects the affinity of SHBG with testosterone, there will be an increase in testosterone.

Testosterone concentrations in this study varied between young bucks and adult bucks with significant difference. This shows that testosterone concentration is influenced by age. This study corroborates previous studies that report higher testosterone concentrations found in young Kejobong bucks than adults, with concentrations of $19.62 \pm 4.86 \mathrm{ng} / \mathrm{mL}$ and $16.12 \pm 6.47 \mathrm{ng} / \mathrm{mL}$, respectively (Syamyono et al. 2015).

Other age-related studies in bucks have been reported in Shiba bucks by Hannan et al. (2017), who found no significant differences in testosterone concentrations between the period of early and late puberty. A sharp increase $(\mathrm{P}<0.01)$ was found during the post-pubertal 
period (34-52 weeks) compared with the initial and late puberty period (<34 weeks). Meanwhile, previous studies on Anglo Nubian goats in semi-intensive farm systems, with 5 months and 9.5 months of age, had testosterone concentrations of $2.7 \pm 1.4 \mathrm{ng} / \mathrm{mL}^{-1}, 8.5 \pm 4.6 \mathrm{ng} / \mathrm{mL}^{-1}$, and $2.2 \pm 2.2 \mathrm{ng} / \mathrm{mL}^{-1} \quad$ (Souza et al. 2011). Furthermore, according to Hannan et al. (2017), and Hannan et al. (2019), the concentration of testosterone secreted in male animals is more volatile, so that individual variation factors become the main determinant of the concentration obtained. Therefore, it is necessary to conduct research using a larger sample number and repeat sample collections in the future.

\section{Libido}

Breed and age factors, as well as the interaction of the two factors, show no significant effect on libido $(\mathrm{P}>0.05)$ (Table 3). Level of libido is not affected by breed and goat age. Likewise, there is no interaction between breed and age on libido.
This study finds that libido levels are not significantly different $(\mathrm{P}>0.05)$ across different breeds and ages. Libido levels in this study were similar to studies comparing levels between Kiko and Boer breeds, with no significant difference ( $\mathrm{P}>0.05)$ (Ford Jr et al. 2009). Previous studies show that libido scores vary more among some animals (Rhen and Crews 2002; Younis et al. 2003; Ahmad et al. 2005; Kondracki et al. 2013; Affandhy et al. 2018). Therefore, the libido levels obtained in this study indicate no significant differences based on breed.

Effects of age group on libido in goats have not been widely reported. However, the effects of age Rehman et al. (2016) determined higher libido in adult bulls. This supports Petherick (2005), which found that libido expression is higher in adult bulls, although levels in bulls vary by breed. The libido score obtained in this study differs from other studies, possibly caused by differences in the libido measurement methods.

Table 1. Adiponectin concentration $(\mu \mathrm{g} / \mathrm{mL})^{\mathrm{TR}}$ in Anglo Nubian bucks, Etawah grade and Anpera

\begin{tabular}{|c|c|c|c|c|c|c|}
\hline \multirow[b]{2}{*}{ Breed } & \multicolumn{2}{|c|}{ Age } & \multirow[b]{2}{*}{ Mean } & \multicolumn{3}{|c|}{ Level of significance } \\
\hline & $\begin{array}{c}\text { Young } \\
\text { (18-24 months) }\end{array}$ & $\begin{array}{c}\text { Adult } \\
\text { (30-42 months) }\end{array}$ & & Age & Breed & Interaction \\
\hline Anglo Nubian $(n=4)$ & $3.91 \pm 0.33 b$ & $5.39 \pm 0.20 \mathrm{a}$ & $4.65 \pm 1.01 \mathrm{~B}$ & $*$ & $* *$ & $* *$ \\
\hline Etawah grade $(n=4)$ & $2.88 \pm 0.08 \mathrm{c}$ & $2.98 \pm 0.13 \mathrm{c}$ & $2.93 \pm 0.21 \mathrm{C}$ & & & \\
\hline Anpera $(n=4)$ & $5.85 \pm 0.24 \mathrm{a}$ & $5.37 \pm 0.19 \mathrm{a}$ & $5.61 \pm 0.96 \mathrm{~A}$ & & & \\
\hline Mean & $4.21 \pm 0.87 \mathrm{~B}$ & $4.58 \pm 0.80 \mathrm{~A}$ & & & & \\
\hline
\end{tabular}

Table 2. Testosterone concentration (ng/mL) in Anglo Nubian bucks, Etawah grade and Anpera

\begin{tabular}{|c|c|c|c|c|c|c|}
\hline \multirow[b]{2}{*}{ Breed } & \multicolumn{2}{|c|}{ Age } & \multirow[b]{2}{*}{ Mean } & \multicolumn{3}{|c|}{ Level of significance } \\
\hline & $\begin{array}{c}\text { Young } \\
\text { (18-24 months) }\end{array}$ & $\begin{array}{c}\text { Adult } \\
\text { (30-42 months) }\end{array}$ & & Age & Breed & Interaction \\
\hline Anglo Nubian $(n=4)$ & $16.24 \pm 1.03 a$ & $7.76 \pm 2.12 b$ & $12.00 \pm 2.70 \mathrm{AB}$ & $*$ & $*$ & $* *$ \\
\hline Etawah grade $(n=4)$ & $11.33 \pm 1.31 b$ & $6.98 \pm 0.58 b$ & $9.15 \pm 2.12 \mathrm{~B}$ & & & \\
\hline Anpera $(n=4)$ & $11.64 \pm 0.93 a$ & $15.37 \pm 2.56 \mathrm{a}$ & $13.50 \pm 1.21 \mathrm{~A}$ & & & \\
\hline Mean & $13.07 \pm 1.59 \mathrm{~A}$ & $10.04 \pm 2.68 \mathrm{~B}$ & & & & \\
\hline
\end{tabular}

Note: $* \mathrm{P}<0.05$. $* * \mathrm{P}<0.01 .{ }^{\mathrm{AB}}$ Different superscripts in the same row of mean (age) and column of mean (breed) indicate significant differences among means $(\mathrm{P}<0.05)$. ${ }^{\mathrm{b}}$ Different superscripts in the combination of age and breed indicate significant differences among means $(\mathrm{P}<0.01)$.

Table 3. Libido (score) ${ }^{\mathrm{TR}}$ in Anglo Nubian bucks, Etawah grade and Anpera

\begin{tabular}{|c|c|c|c|c|c|c|}
\hline \multirow[b]{2}{*}{ Breed } & \multicolumn{2}{|c|}{ Age } & \multirow[b]{2}{*}{ Mean } & \multicolumn{3}{|c|}{ Level of significance } \\
\hline & $\begin{array}{c}\text { Young } \\
\text { (18-24 months) } \\
\end{array}$ & $\begin{array}{c}\text { Adult } \\
\text { (30-42 months) }\end{array}$ & & Age & Breed & Interaction \\
\hline Anglo Nubian & $3.18 \pm 0.06$ & $3.15 \pm 0.04$ & $3.16 \pm 0.05$ & ns & ns & ns \\
\hline Etawah grade & $3.00 \pm 0.05$ & $3.08 \pm 0.05$ & $3.04 \pm 0.07$ & & & \\
\hline Anpera & $3.08 \pm 0.05$ & $3.08 \pm 0.11$ & $3.08 \pm 0.04$ & & & \\
\hline Mean & $3.09 \pm 0.05$ & $3.10 \pm 0.02$ & & & & \\
\hline
\end{tabular}

Note: ${ }^{\mathrm{TR}}$ transformation data $(x+0.5)^{1 / 2} ; x=$ original data. $\mathrm{ns}=$ not significant. 


\section{Characteristics of semen \\ Semen volume}

The characteristics of semen reported in this study consisted of semen volume, sperm motility, sperm morphology, and sperm concentration. Factors of breed, age, and age-breed interaction with semen volume show no significant difference $(\mathrm{P}>0.05)$ (Table 4).

This study determines that semen characteristics based on breed and age group, and age-breed interactions, were not significantly different among Anglo Nubian, Etawah grade and Anpera bucks (P> 0.05). In general, the characteristics of semen were similar to those reported by Elhammali et al. (2013) in crossbred bucks (Pure Nubian $x$ Pure Saanen), and Syamyono et al. (2014) in Kejobong bucks. However, some studies report that male reproductive performance, in general, is influenced by factors such as management, age, nutrition and body weight (Galina et al. 2007; Rehman et al. 2016).

This study corroborates reports by Atara et al. (2018), who found the volume of semen in Surti bucks is higher in adults compared to young. Likewise, Suyadi (2012) finds semen volume does not differ between age groups of Boer bucks.

\section{Sperm motility}

Breed and age factors, as well as the interaction of the two factors, show no significant difference in affecting sperm motility ( $\mathrm{P}>0.05)$ (Table 5).

The sperm motility found in this study shows no significant difference based on breed or age. Praharani and Sianturi (2014) found there were no significant differences in motility and morphology of sperm between breeds. Atara et al. (2018) determined effects of age on semen characteristics in Surti bucks. However, in Boer (Suyadi
2012), and Red Sokoto bucks (Akpa et al. 2013), there were no such differences based on age.

\section{Sperm normal morphology}

Breed and age factors, as well as the interaction of these two factors, show no significant effect on the sperm normal morphology ( $\mathrm{P}>0.05)$ (Table 6).

The sperm normal morphology found in this study shows no significant difference based on breed or age. Praharani and Sianturi (2014) find there are no significant differences between breeds regarding sperm morphology.

\section{Sperm concentration}

Breed and age factors, and the interaction of these two factors, show no significant effect on sperm concentration (P> 0.05) (Table 7).

Sperm concentration in this study shows no significant difference between age groups and breed. Suyadi (2012) finds there are no significant differences in sperm concentrations based on buck age. In contrast, Atara et al. (2018) determined age-based differences on sperm concentration.

\section{Heterosis effect}

The heterosis effect obtained in this study was determined from the concentration of adiponectin, testosterone concentration, libido, semen volume, sperm motility, sperm normal morphology, and sperm concentration $48.05 \%, 27.68 \%,-0.61 \%,-1.93 \%, 0.49 \%$, $0.18 \%$, and $0.00 \%$, respectively (Table 8 ).

Heterosis is a term used to measure crossbred performance compared to the average performance of parents (Wakchaure et al. 2015). The effects of heterosis can be either positive or negative, and for reproductive performance generally, the effect of heterosis is negative (Cassady et al. 2002; Sutiyono et al. 2011).

Table 4. Semen volume $(\mathrm{ml})^{\mathrm{TR}}$ in Anglo Nubian bucks, Etawah grade and Anpera

\begin{tabular}{|c|c|c|c|c|c|c|}
\hline \multirow[b]{2}{*}{ Breed } & \multicolumn{2}{|c|}{ Age } & \multirow[b]{2}{*}{ Mean } & \multicolumn{3}{|c|}{ Level of significance } \\
\hline & $\begin{array}{c}\text { Young } \\
\text { (18-24 months) }\end{array}$ & $\begin{array}{c}\text { Adult } \\
(30-42 \text { months })\end{array}$ & & Age & Breed & Interaction \\
\hline Anglo Nubian & $1.11 \pm 0.05$ & $1.14 \pm 0.04$ & $1.13 \pm 0.02$ & ns & ns & ns \\
\hline Etawah grade & $1.09 \pm 0.02$ & $1.21 \pm 0.03$ & $1.15 \pm 0.05$ & & & \\
\hline Anpera & $1.14 \pm 0.08$ & $1.08 \pm 0.02$ & $1.12 \pm 0.04$ & & & \\
\hline Mean & $1.11 \pm 0.02$ & $1.14 \pm 0.04$ & & & & \\
\hline
\end{tabular}

Table 5. Sperm motility (\%) in Anglo Nubian bucks, Etawah grade and Anpera

\begin{tabular}{|c|c|c|c|c|c|c|}
\hline \multirow[b]{2}{*}{ Breed } & \multicolumn{2}{|c|}{ Age } & \multirow[b]{2}{*}{ Mean } & \multicolumn{3}{|c|}{ Level of significance } \\
\hline & $\begin{array}{c}\text { Young } \\
(18-24 \text { months })\end{array}$ & $\begin{array}{c}\text { Adult } \\
(30-42 \text { months })\end{array}$ & & Age & Breed & Interaction \\
\hline Anglo Nubian & $76.00 \pm 1.27$ & $73.50 \pm 1.87$ & $74.75 \pm 1.25$ & ns & ns & ns \\
\hline Etawah grade & $75.50 \pm 1.46$ & $80.50 \pm 1.66$ & $78.00 \pm 2.50$ & & & \\
\hline Anpera & $78.00 \pm 2.29$ & $75.50 \pm 1.46$ & $76.75 \pm 1.25$ & & & \\
\hline Mean & $76.50 \pm 0.76$ & $76.50 \pm 2.08$ & & & & \\
\hline
\end{tabular}

Note: ns $=$ not significant. 
Table 6. Sperm normal morphology (\%) in Anglo Nubian bucks, Etawah grade and Anpera

\begin{tabular}{|c|c|c|c|c|c|c|}
\hline \multirow[b]{2}{*}{ Breed } & \multicolumn{2}{|c|}{ Age } & \multirow[b]{2}{*}{ Mean } & \multicolumn{3}{|c|}{ Level of significance } \\
\hline & $\begin{array}{c}\text { Young } \\
(18-24 \text { months })\end{array}$ & $\begin{array}{c}\text { Adult } \\
\text { (30-42 months) }\end{array}$ & & Age & Breed & Interaction \\
\hline Anglo Nubian & $94.42 \pm 2.57$ & $98.66 \pm 0.38$ & $96.54 \pm 2.12$ & ns & ns & ns \\
\hline Etawah grade & $98.68 \pm 0.33$ & $97.56 \pm 0.73$ & $98.12 \pm 0.56$ & & & \\
\hline Anpera & $96.74 \pm 0.72$ & $98.27 \pm 0.51$ & $97.50 \pm 0.77$ & & & \\
\hline Mean & $96.61 \pm 1.23$ & $98.16 \pm 0.32$ & & & & \\
\hline
\end{tabular}

Note: $n s$ = not significant

Table 7. Sperm concentration $\left(\mathrm{x} 10^{9} / \mathrm{mL}\right)^{\mathrm{TR}}$ in Anglo Nubian bucks, Etawah grade and Anpera

\begin{tabular}{|c|c|c|c|c|c|c|}
\hline \multirow[b]{2}{*}{ Breed } & \multicolumn{2}{|c|}{ Age } & \multirow[b]{2}{*}{ Mean } & \multicolumn{3}{|c|}{ Level of significance } \\
\hline & $\begin{array}{c}\text { Young } \\
\text { (18-24 months) }\end{array}$ & $\begin{array}{c}\text { Adult } \\
\text { (30-42 months) }\end{array}$ & & Age & Breed & Interaction \\
\hline Anglo Nubian & $0.86 \pm 0.03$ & $0.88 \pm 0.04$ & $0.87 \pm 0.03$ & ns & ns & ns \\
\hline Etawah grade & $0.99 \pm 0.13$ & $0.89 \pm 0.06$ & $0.94 \pm 0.05$ & & & \\
\hline Anpera & $0.92 \pm 0.10$ & $0.89 \pm 0.06$ & $0.91 \pm 0.04$ & & & \\
\hline Mean & $0.93 \pm 0.04$ & $0.89 \pm 0.05$ & & & & \\
\hline
\end{tabular}

Table 8. The effect of heterosis (\%) on adiponectin concentrations, and reproductive performance in Anpera buck

\begin{tabular}{|c|c|c|c|c|c|}
\hline \multirow[b]{2}{*}{ Parameters } & \multicolumn{4}{|c|}{ Breed } & \multirow[b]{2}{*}{$\begin{array}{c}\text { Heterosis effects } \\
(\%)\end{array}$} \\
\hline & $\begin{array}{c}\text { Anglo Nubian } \\
(n=4)\end{array}$ & $\begin{array}{c}\text { Etawah grade } \\
(n=4)\end{array}$ & $\begin{array}{c}\text { Mean breed elder } \\
\text { performance }\end{array}$ & $\begin{array}{c}\text { Anpera } \\
(n=4)\end{array}$ & \\
\hline Adiponectin $(\mu \mathrm{g} / \mathrm{mL})^{\mathrm{TR}}$ & $4.65 \pm 1.01$ & $2.93 \pm 0.21$ & $3.79 \pm 0.86$ & $5.61 \pm 0.96$ & 48.05 \\
\hline Testosterone (ng/mL) & $12.00 \pm 2.70$ & $9.15 \pm 2.12$ & $10.58 \pm 1.43$ & $13.50 \pm 1.21$ & 27.68 \\
\hline Libido (score) ${ }^{\mathrm{TR}}$ & $3.16 \pm 0.05$ & $3.04 \pm 0.07$ & $3.10 \pm 0.06$ & $3.08 \pm 0.04$ & -0.61 \\
\hline Semen Volume $(\mathrm{ml})^{\mathrm{TR}}$ & $1.13 \pm 0.02$ & $1.15 \pm 0.06$ & $1.14 \pm 0.01$ & $1.12 \pm 0.05$ & -1.93 \\
\hline Sperm motility (\%) & $74.75 \pm 3.75$ & $78.00 \pm 1.47$ & $76.38 \pm 1.63$ & $76.75 \pm 0.75$ & 0.49 \\
\hline Sperm normal morphology (\%) & $96.54 \pm 1.83$ & $98.12 \pm 0.42$ & $97.33 \pm 0.33$ & $97.50 \pm 0.48$ & 0.18 \\
\hline Sperm concentration $\left(\times 10^{9} / \mathrm{mL}\right)^{\mathrm{TR}}$ & $0.87 \pm 0.03$ & $0.94 \pm 0.05$ & $0.91 \pm 0.03$ & $0.91 \pm 0.04$ & 0.00 \\
\hline
\end{tabular}

Note: ${ }^{\mathrm{TR}}$ transformation data $(x+0.5)^{1 / 2} ; x=$ original data

Research by Mahal et al. (2013) and Mia et al. (2013) shows that goat semen characteristics such as semen volume, sperm motility, normal morphology of sperm and higher sperm concentration are influenced by non-genetic factors. Praharani and Sianturi (2014) found heterosis values in crossbred bucks for semen volume, sperm motility, sperm concentration and sperm abnormalities were $0.71 \%, 0.52 \%, 1.90 \%$ and $18.96 \%$, respectively. Therefore, negative effects on reproductive performance in crossbred bucks are normal (Cassady et al. 2002; Sutiyono et al. 2011). It also shows that reproductive performance, especially in goats, is less influenced by genetic factors than other factors, such as management and external environment.

In sum, this study concludes that buck age, breed, and age-breed interactions affect adiponectin and testosterone concentration. In comparison, libido and semen characteristics show no significant differences based on breed and age group. Heterosis effects on the hormones adiponectin and testosterone are high, but low on libido and sperm morphology, motility, volume, and concentration.

\section{ACKNOWLEDGEMENTS}

This work was supported by the Ministry of Research, Technology and Higher Education of The Republic of Indonesia, through Universitas Syiah Kuala under the project Research Grant 2018 (Grant number: 18/UN11.2/PP/SP3/2018). The author also wishes to acknowledge the Indonesian Research Institute for Animal Production for providing permission to use the experimental animal. Special appreciation, gratefully acknowledges to Dr. G. Gholib (Universitas Syiah Kuala, Banda Aceh, Indonesia) for ELISA technical assistance, and to Asep Rusyana for review of statistics, statistical analysis and interpretation.

\section{REFERENCES}

Affandhy L, Fitrayady H, Luthfi M, Widyaningrum Y. 2018. Effect of live weight on libido, sperm quality, testosterone and luteinizing hormone in replacement stock of Ongole Grade bull. J Indonesian Trop Anim Agric 43 (4): 352-360. 
Ahmad M, Asmat M, Rehman N. 2005. Relationship of testicular size and libido to age and season in Sahiwal bulls. Pak Vet J 25 (2): 67-70.

Akpa G, Ambali A, Suleiman I. 2013. Body conformation, testicular and semen characteristics as influenced by age, hair type and body condition of Red Sokoto goat. N Y Sci J 6 (7): 44-58.

Amal A, Arifiantini R, Setiadi M, Said S. 2019. Characteristics of the post-thawed Balinese bull semen extended in three different extenders and equilibration times. J Indonesian Trop Anim Agric 44 (2): 135145.

Arief A, Rusdimansyah R, Sowmen S, Pazla R, Rizqan R. 2020. Milk production and quality of Etawa crossbreed dairy goat that given Tithonia diversifolia, corn waste and concentrate based palm kernel cake. Biodiversitas 21 (9): 4004-4009.

Armansyah T, Barat ERP, Handini CVR, Aliza D, Sutriana A, Hamdan H, Panjaitan B, Sayuti A, Siregar TN. 2018. Concentration and motility of spermatozoa and testosterone level of Kacang goat after seminal vesicle extract administration. Open Vet J 8 (4): 401-410. DOI: 10.4314/ovj.v8i4.9.

Atara V, Chaudhari C, Ramani U, Chaudhary M, Patel D, Patel Y, Patel N. 2018. Semen characteristics in young and adult Surti buck. Indian J Anim Hlth 57 (2): 219-224.

Ayina CNA, Noubiap JJN, Etoundi Ngoa LS, Boudou P, Gautier JF, Mengnjo MK, Mbanya JC, Sobngwi E. 2016. Association of serum leptin and adiponectin with anthropomorphic indices of obesity, blood lipids and insulin resistance in a Sub-Saharan African population. Lipids Health Dis 15 (96): 1-11. DOI: 10.1186/s12944-016-0264-X.

Boe-Hansen GB, Rego JPA, Crisp JM, Moura AA, Nouwens AS, Li Y, Venus B, Burns BM, McGowan MR. 2015. Seminal plasma proteins and their relationship with percentage of morphologically normal sperm in 2-year-old Brahman (Bos indicus) bulls. Anim Reprod Sci 162: 20-30. DOI: 10.1016/j.anireprosci.2015.09.003.

Cassady JP, Young LD, Leymaster KA. 2002. Heterosis and recombination effects on pig reproductive traits. J Anim Sci 80 (9): 2303-2315. DOI: 10.1093/ansci/80.9.2303.

Cawthorn WP, Scheller EL, MacDougald OA. 2012. Adipose tissue stem cells meet preadipocyte commitment: going back to the future. J Lipid Res 53 (2): 227-246. DOI: 10.1194/jlr.R021089.

Chilliard Y, Delavaud C, Bonnet M. 2005. Leptin expression in ruminants: nutritional and physiological regulations in relation with energy metabolism. Domest Anim Endocrin 29 (1): 3-22. DOI: 10.1016/j.domaniend.2005.02.026.

Choubey M, Ranjan A, Bora PS, Baltazar F, Martin LJ, Krishna A. 2019. Role of adiponectin as a modulator of testicular function during aging in mice. Biochim Biophys Acta 1865 (2): 413-427. DOI: 10.1016/j.bbadis.2018.11.019.

Cnop M, Havel PJ, Utzschneider KM, Carr DB, Sinha MK, Boyko EJ, Retzlaff BM, Knopp RH, Brunzell JD, Kahn SE. 2003. Relationship of adiponectin to body fat distribution, insulin sensitivity and plasma lipoproteins: Evidence for independent roles of age and sex. Diabetologia 46 (4): 459-469. DOI: 10.1007/s00125-003-1074-z.

Elfassy Y, Bastard J-P, McAvoy C, Fellahi S, Dupont J, Levy R. 2018. Adipokines in semen: physiopathology and effects on spermatozoas. Int J Endocrinol 2018: 1-11. DOI: 10.1155/2018/3906490.

Elhammali N, Alqurashi AM, Ibrahim MT, Elsheikh A. 2013. Puberty of crossbred male goat kids. J Am Sci 9 (4): 95-99.

Fahey A, Duffy P, Fair S. 2012. Effect of exposing rams to a female stimulus before semen collection on ram libido and semen quality. J Anim Sci 90 (10): 3451-3456. DOI: 10.2527/jas.2011-4859

Ferasyi TR, Akmal M, Hamdani B, Razali, Azhari, Wahyuni S, Amiruddin, Anwar, Pamungkas FA, Nasution S, Barus RA. 2015. Potency of combination of palm kernel meal and katuk leaf powder to improve the production performance of Peranakan Etawa (PE) goat: Toward a strategy for quality control of meat using "CGE" concept. Procedia Food Sci 3: 389-395. DOI: 10.1016/j.profoo.2015.01.043

Ford JD, Okere C, Bolden-Tiller O. 2009. Libido test scores, body conformation and testicular traits in boer and Kiko goat bucks. J Agri Biol Sci 4 (5): 54-61

Galina CS, Horn MM, Molina R. 2007. Reproductive behaviour in bulls raised under tropical and subtropical conditions. Horm Behav 52 (1): 26-31. DOI: 10.1016/j.yhbeh.2007.03.026.

Gholib G, Wahyuni S, Kadar OH, Adam M, Lubis TM, Azhar A, Akmal M, Siregar TN, Armansyah T, Nugraha TP. 2016. Measurement of serum testosterone in Kacang goat by using enzyme-linked immunosorbent assay (ELISA) technique: The importance of kit validation J Kedokt Hewan 10 (1): 32-36. DOI: 10.21157/j.ked.hewan.v10i1.3367.
Hafizuddin H, Karja NWK, Praharani L, Setiadi MA. 2019. Adiponektin: Hormon protein potensial sebagai kandidat biomarker kesuburan $\begin{array}{lllll}\text { pejantan. Wartazoa } 29 & \text { (4): 183-192. DOI: }\end{array}$ 10.14334/wartazoa.v29i4.2063.

Hafizuddin H, Karja NWK, Praharani L, Setiadi MA. 2020. Adiponectin and testosterone levels and its correlation with fertility in AngloNubian x Etawah Grade crossbred bucks. Trop Anim Sci J 43 (2): 110-116. DOI: $10.5398 /$ tasj.2020.43.2.110.

Hannan MA, Kawate N, Fukami Y, Weerakoon WWPN, Büllesbach EE, Inaba T, Tamada H. 2017. Changes of plasma concentrations of insulin-like peptide 3 and testosterone, and their association with scrotal circumference during pubertal development in male goats. Theriogenology 92: 51-56. 10.1016/j.theriogenology.2017.01.009.

Hannan MA, Murase H, Sato F, Tsogtgerel M, Kawate N, Nambo Y. 2019. Age related and seasonal changes of plasma concentrations of insulinlike peptide 3 and testosterone from birth to early-puberty in Thoroughbred male horses. Theriogenology 132: 212-217. DOI: 10.1016/j.theriogenology.2019.04.014

Heinz JF, Singh SP, Janowitz U, Hoelker M, Tesfaye D, Schellander K, Sauerwein H. 2015. Characterization of adiponectin concentrations and molecular weight forms in serum, seminal plasma, and ovarian follicular fluid from cattle. Theriogenology 83 (3): 326-333. DOI: 10.1016/j.theriogenology.2014.06.030.

Kadivar A, Khoei HH, Hassanpour H, Golestanfar A, Ghanaei H. 2016. Correlation of adiponectin mRNA abundance and its receptors with quantitative parameters of sperm motility in rams. Int J Fertil Steril 10 (1): 127. DOI: $10.22074 /$ ijfs.2016.4778.

Kasimanickam VR, Kasimanickam RK, Kastelic JP, Stevenson JS. 2013. Associations of adiponectin and fertility estimates in Holstein bulls. $\begin{array}{llll}\text { Theriogenology } & 79 & \text { (5): }\end{array}$ 10.1016/j.theriogenology.2012.12.0

Kondracki S, Iwanina M, Wysokińska A, Górski K. 2013. The use of sexual activity measurements to assess ejaculatory performance of boars. Archiv fuer Tierzucht 56 (1): 1052-1059. DOI: 10.7482/00039438-56-106.

Mahal Z, Khandoker M, Haque M. 2013. Effect of non genetic factors on productive traits of Black Bengal goats. J Bangladesh Agril Univ 11 (1): 79-86. DOI: 10.3329/jbau.v11i1.18217.

Maidin MS, Padlan M, Azuan S, Jonit R, Mohammed N, Abdullah R. 2018. Supplementation of Nigella sativa oil and honey prolong the survival rate of fresh and post-thawed goat sperms. Trop Anim Sci J 41 (2): 94-99. DOI: 10.5398/tasj.2018.41.2.94.

Mia M, Khandoker M, Husain S, Faruque M, Notter D, Apu A. 2013. Genetic and phenotypic parameters for semen characteristics and their relationship with scrotal circumference in Black Bengal bucks. Iran J Appl Anim Sci 3 (4): 709-717.

Mickelsen WD, Paisley LG, Dahmen JJ. 1982. The relationship of libido and serving capacity test scores in rams on conception rates and lambing percentage in the ewe. Theriogenology 18 (1): 79-86. DOI: 10.1016/0093-691X (82)90051-6.

Mirkena T, Duguma G, Haile A, Tibbo M, Okeyo AM, Wurzinger M, Sölkner J. 2010. Genetics of adaptation in domestic farm animals: A review. Livest Sci 132 (1): 1-12. DOI: 10.1016/j.livsci.2010.05.003.

Ohlsson C, Wallaschofski H, Lunetta KL, Stolk L, Perry JRB, Koster A, Petersen A-K, Eriksson J, Lehtimäki T, Huhtaniemi IT, Hammond GL, Maggio M, Coviello AD, Group ES, Ferrucci L, Heier M, Hofman A, Holliday KL, Jansson J-O, Kähönen M, Karasik D, Karlsson MK, Kiel DP, Liu Y, Ljunggren Ö, Lorentzon M, Lyytikäinen L-P, Meitinger T, Mellström D, Melzer D, Miljkovic I, Nauck M, Nilsson M, Penninx B, Pye SR, Vasan RS, Reincke M, Rivadeneira F, Tajar A, Teumer A, Uitterlinden AG, Ulloor J, Viikari J, Völker U, Völzke H, Wichmann HE, Wu T-S, Zhuang WV, Ziv E, Wu FCW, Raitakari O, Eriksson A, Bidlingmaier M, Harris TB, Murray A, de Jong FH, Murabito JM, Bhasin S, Vandenput L, Haring R. 2011. Genetic determinants of serum testosterone concentrations in men. PLoS Genetics 7 (10): e1002313. DOI: 10.1371/journal.pgen.1002313.

Pearson LK. 2015. Adiponectin in Equine Reproduction [Dissertation]. Washington State University, Washington (US).

Petherick JC. 2005. A review of some factors affecting the expression of libido in beef cattle, and individual bull and herd fertility. Appl Anim Behav Sci 90 (3): 185-205. DOI: 10.1016/j.applanim.2004.08.021.

Pfaehler A, Nanjappa MK, Coleman ES, Mansour M, Wanders D, Plaisance EP, Judd RL, Akingbemi BT. 2012. Regulation of adiponectin secretion by soy isoflavones has implication for 
endocrine function of the testis. Toxicol Lett 209 (1): 78-85. DOI: 10.1016/j.toxlet.2011.11.027.

Pfeffer PL, Sisco B, Donnison M, Somers J, Smith C. 2007. Isolation of genes associated with developmental competency of bovine oocytes. $\begin{array}{lllll}\text { Theriogenology } & 68 & (1): & \text { S84-S90. } & \text { DOI }\end{array}$ 10.1016/j.theriogenology.2007.03.016.

Praharani L, Anggraeni A, Hapsari A. 2019. Heterosis on morphometric traits of crossbreds from Anglo Nubian and Etawah Grade goats. IOP Conf Ser Earth Environ Sci. 387 (1): 1-4.doi: 10.1088/17551315/387/1/012024.

Praharani L, Sianturi R. 2014. Pengaruh genetik terhadap karakteristik semen pada kambing perah anglo nubian, peranakan etawah dan persilangannya. Di dalam: Pamungkas D, Widiawati $Y$, Noor S, Purwantari N, Widiastuti R, Brahmantiyo B, Herawati T, Kusumaningsih A, Handiwirawan E, Puastuti W (eds.) Prosiding Teknologi Peternakan dan Veteriner Mendukung Pertanian Bioindustri Berkelanjutan, Seminar Nasional Teknologi Peternakan dan Veteriner. Malang, September 12-14 2014. [Indonesian]

Rachmawati L, Ismaya I, Astuti P. 2014. Level of testosterone, libido, and sperm quality of Bligon, Kejobong, and Etawah crossbred bucks. Anim Prod 15 (2): 76-82.

Rehman H, Alhidary I, Khan R, Qureshi M, Sadique U, Khan H, Yaqoob S. 2016. Relationship of age, breed and libido with semen traits of cattle bulls. Pak J Zool 48: 1793-1798.

Ren MQ, Wegner J, Bellmann O, Brockmann GA, Schneider F, Teuscher F, Ender K. 2002. Comparing mRNA levels of genes encoding leptin, leptin receptor, and lipoprotein lipase between dairy and beef cattle. Domest Anim Endocrin 23 (3): 371-381. DOI: 10.1016/s0739-7240 (02)00179-0.

Rhen T, Crews D. 2002. Variation in reproductive behaviour within a sex: neural systems and endocrine activation. J Neuroendocrinol 14 (7): $517-531$

Sahraoui H, Madani T, Fantazi K, Khouane AC, Ameur AA, Paschino P, Vacca GM, Gaouar SBS, Dettori ML. 2020. Genetic variability in the A microsatellite at SLC11A1 gene and possible implications with innate resistance against brucellosis in Algerian native goats. Biodiversitas 21 (12): 5630-5636. DOI: 10.13057/biodiv/d211219.

Singh A, Brar P, Cheema R. 2014. Relationships among frozen-thawed semen fertility, physical parameters, certain routine sperm characteristics and testosterone in breeding Murrah buffalo (Bubalus bubalis) bulls. Vet World 7 (9): 644-651. DOI 10.14202/vetworld.2014.644-651.

Souza L, Cruz J, Neto M, Nunes R, Cruz M. 2011. Puberty and sexual maturity in Anglo-Nubian male goats raised in semi-intensive system.
Rev Bras Zootecn 40 (7): 1533-1539. DOI: $10.1590 /$ S151635982011000700019 .

Sutarno S, Setyawan A. 2015. Genetic diversity of local and exotic cattle and their crossbreeding impact on the quality of Indonesian cattle. Biodiversitas 16 (2): 327-354. DOI: 10.13057/biodiv/d160230.

Sutiyono B, Soedarsono S, Johari S, Ondho YS. 2011. Efek heterosis berbagai penampilan tiktok jantan dan betina. Bul Pet 35 (3): 153-159. DOI: $10.21059 /$ buletinpeternak.v35i3.1087.

Suyadi S. 2012. Sexual behaviour and semen characteristics of young male Boer goats in tropical condition: a case in Indonesia. World Acad Sci Eng Technol 6 (6): 388-391.

Syafruddin S, Iryandi F, Rahmi RAS, Husnurrizal H, Armansyah T, Panjaitan B, Sayuti A, Sutriana A, Aliza D, Hafizuddin H, Siregar TN. 2020. The effect of gonadotropin-releasing hormone $(\mathrm{GnRH})$ on semen quality and testosterone level of Nubian goats. Vet Med Zoot 77 (99): 16-21.

Syamyono O, Samsudewa D, Setiatin E. 2014. Korelasi lingkar skrotum dengan bobot badan, volume semen, kualitas semen, dan kadar testosteron pada kambing kejobong muda dan dewasa. Bul Pet 38 (3): 132-140. DOI: 10.21059/buletinpeternak.v38i3.5248.

Syamyono O, Samsudewa D, Setiatin ET. 2015. Karakteristik semen dan kadar testosteron berdasarkan ukuran lingkar skrotum kambing kejobong muda dan dewasa J Vet 16 (2): 256-264.

Thomas S, Kratzsch D, Schaab M, Scholz M, Grunewald S, Thiery J, Paasch U, Kratzsch J. 2013. Seminal plasma adipokine levels are correlated with functional characteristics of spermatozoa. Fertil Steril 99 (5): 1256-1263.e1253. DOI: 10.1016/j.fertnstert.2012.12.022.

Ting-Ting W, Ying-Ying Z, Yi-Ning Y, Xiao-Mei L, Yi-Tong M, Xiang X. 2019. Age, sex, and cardiovascular risk attributable to lipoprotein cholesterol among Chinese individuals with coronary artery disease: a case-control study. Metab Syndr Relat Disord 17 (4): 223-231. DOI: 10.1089/met.2018.0067.

Wakchaure R, Ganguly S, Praveen K, Sharma S, Kumar A, Mahajan T, Qadri K. 2015. Importance of heterosis in animals: a review. Int J Innov Res Sci Eng 1 (1): 1-5.

Younis M, Samad H, Ahmad N, Ahmad I. 2003. Effects of age and season on the body weight, scrotal circumference and libido in nili-ravi buffalo bulls maintained at the Semen Production Unit, Qadirabad. Pak Vet J 23 (2): 59-65.

Yu P, Yuan R, Yang X, Qi Z. 2019. Adipose tissue, aging, and metabolism. Curr Opin Endocr Metab Res 5: 11-20. DOI: 10.1016/j.coemr.2019.02.003. 